\title{
Effect of electrode material and supporting electrolyte on the treatment of water containing Escherichia coli by electrocoagulation
}

\author{
A. C. Ndjomgoue-Yossa $\cdot$ C. P. Nanseu-Njiki • \\ I. M. Kengne $\cdot$ E. Ngameni
}

Received: 20 July 2012/Revised: 22 December 2013/Accepted: 28 April 2014/Published online: 15 May 2014

(C) Islamic Azad University (IAU) 2014

\begin{abstract}
Laboratory experiments were carried out to investigate the mechanisms of electrochemical disinfection of artificial wastewater contaminated by Escherichia coli culture $\left(5 \times 10^{5} \mathrm{UFC} / 100 \mathrm{~mL}\right)$ using electrocoagulation. In order to go deeply into the mechanism of the process, the behaviors of two dissolved-type electrodes (ordinary steel and aluminum) and a non-dissolved-type (carbon graphite) electrode were compared. The ordinary steel electrode was found more efficient for $E$. coli cells destruction compared to aluminum and carbon graphite electrodes. In order to determine the most favorable condition for the treatment, the effect of various supporting electrolytes including, sodium chloride, sodium sulfate and sodium nitrate, was scrutinized. E. coli is inactivated by $5 \log$ units for a charge loading of $37.30 \mathrm{~F} / \mathrm{m}^{3}$ for sodium sulfate, $24.87 \mathrm{~F} / \mathrm{m}^{3}$ for sodium nitrate and $12.43 \mathrm{~F} / \mathrm{m}^{3}$ for sodium chloride. It thus appears that the most favorable supporting electrolyte type for this method of disinfection is sodium chloride, a fact which can be explained by the formation of disinfectant byproducts such as chlorine dioxide, hypochlorite ions and perchlorate ions. From the results obtained, electrocoagulation applied to the elimination of E. coli proceeds through three combined effects: the electric field, the actions of oxidants electrogenerated during the process and the adsorption by the metallic hydroxides formed in solution.
\end{abstract}

A. C. Ndjomgoue-Yossa · C. P. Nanseu-Njiki ( $\square)$.

E. Ngameni

Laboratoire de Chimie Analytique, Faculté des Sciences,

Université de Yaoundé I, B P 812, Yaoundé, Cameroun

e-mail: nanseu@yahoo.fr

\section{M. Kengne}

Laboratory of Plant Biotechnology and Environment, Faculty of

Sciences, Yaoundé I University, P.O Box 812, Yaoundé,

Cameroun
Keywords Electrochemical disinfection . Electrocoagulation · Electrode material $\cdot$ Escherichia coli . Supporting electrolyte

\section{Introduction}

Disinfection is the main barrier against pathogenic microorganisms before water distribution network. Chlorination is traditionally the most dominant method of disinfection (Longley 1986). Despite the high doses of disinfectants used during chlorination, some microorganisms such as Escherichia coli (E. coli) and Cryptosporidium parvum are frequently isolated in water supply, i.e., they are resistant to chlorine (Abu-Shkara et al. 1998; Driedger et al. 2000). Chlorination also leads to various other disadvantages such as the generation of potentially toxic disinfection by-products: $\mathrm{ClO}_{2}, \mathrm{ClO}^{-}$and $\mathrm{ClO}_{4}{ }^{-}$(Bull et al. 2001). As a result of those disadvantages, a number of alternatives to chlorine for drinking water disinfection have been suggested. They can be of: (1) chemical nature such as ozonation; (2) physicochemical nature such as titanium photocatalysis, photodynamic disinfection and electrochemical disinfection; (3) and physical such as ultraviolet irradiation, pulsed electric fields and irradiation magnetic enhanced disinfection (Kerwick et al. 2005). Apart from electrochemical disinfection, most of these systems are quite expensive and thus less convenient. Electrochemical disinfection has gained increasing attention as an alternative for the conventional methods of disinfection, since it is environmentally friendly and is known to inactivate a wide variety of microorganisms from bacteria to viruses and algae (Diao et al. 2004; Jeong et al. 2006, 2009).

Various mechanisms have been proposed to explain how the electrochemical disinfection proceeds: They include the 
formation of disinfectant by-products such as $\mathrm{ClO}_{2}, \mathrm{ClO}^{-}$ and $\mathrm{ClO}_{4}{ }^{-}$(Bergmann and Rollin 2007); and the electrogeneration of disinfection by-products, especially in the case where chloride ions are present such as the following active chlorine species $\mathrm{Cl}_{2}, \mathrm{HOCl}$ and $\mathrm{OCl}^{-}$. It was eventually demonstrated that even at very low chloride concentrations $\left(<100 \mathrm{mg} \mathrm{L}^{-1}\right)$, sufficient free chlorine can be electrochemically produced to efficiently disinfect water (Bergmann and Koparal 2005). The role of reactive oxygen species, $\mathrm{OH}, \mathrm{O}_{3}, \mathrm{H}_{2} \mathrm{O}_{2}$ and $\mathrm{O}_{2}^{-}$, has been recently underlined for their higher disinfection activity in electrochemical disinfection compared to that of electrochlorination (Jeong et al. 2006). Some other oxidants such as $\mathrm{S}_{2} \mathrm{O}_{8}{ }^{2-}, \mathrm{C}_{2} \mathrm{O}_{6}{ }^{2-}$ and $\mathrm{P}_{2} \mathrm{O}_{8}{ }^{2-}$ can be generated when $\mathrm{SO}_{4}{ }^{2-}, \mathrm{CO}_{3}{ }^{2-}$ and $\mathrm{PO}_{4}{ }^{3-}$ are used as electrolyte with a specific electrode material (Cañizares et al. 2005). All these oxidants can induce oxidative stress and cells death. Another mechanism of electrochemical disinfection involving the effect of electric fields which leads to the irreversible permeabilization of cell membrane has been established (Birbir et al. 2009; Drees et al. 2003).

In recent years, investigations have been focused on the treatment of water and wastewater using electrocoagulation. Electrocoagulation has been widely and successfully been introduced to treat numerous types of wastewater including municipal wastewater, dyeing wastewater and wastewater contaminated with organic species such as phenol (Chen et al. 2000; Mollah et al. 2004; Yildiz et al. 2008). It also has been demonstrated to be effective in removal from water of contamination such as by fluoride, arsenic, Mercury(II), heavy metal, turbidity, virus and algae (Gao et al. 2010; Nanseu-Njiki et al. 2009; Zhu et al. 2005).

Electrocoagulation not only provides a fast rate of pollutant removal and simplicity of operation, but also requires no chemical additive. Therefore, it would produce less sludge (Essadki et al. 2008; Igne 1998). These beneficial properties render electrocoagulation more suitable than conventional physicochemical treatment processes.

The objective of this study was to examine how performant is electrocoagulation as a disinfectant technique applied to the elimination of microorganisms. Indeed, some studies have already been devoted to this subject, but many aspects of the process remain unknown such as the influence of the key parameters of electrocoagulation (Ghernaout et al. 2008; Zhu et al. 2005). In order to elucidate the role of the flocs formed during electrocoagulation on the inactivation of $E$. coli, the work will focused on the effect of electrode material and supporting electrolyte. For this to be achieved, the behaviors of two dissolved-type electrodes (ordinary steel and aluminum) and a non-dissolved-type (carbon graphite) electrode were compared. Furthermore, sodium chloride, sodium sulfate and sodium nitrate electrolytes were used to assess the efficiency of inactivation during electrocoagulation.

This work was done from February 2010 to January 2012 in two laboratories: "Laboratoire de Chimie Analytique, Faculty of Sciences, Yaoundé I University" and "Laboratory of Plant Biotechnology and Environment, Faculty of Sciences, Yaoundé I University."

\section{Materials and methods}

\section{Experimental apparatus}

The experiments were conducted at the laboratory scale, using an electrocoagulation unit consisting of a $100-\mathrm{mL}$ electrochemical reactor and a separator. The reactor has two electrodes plate of dimensions of $10 \mathrm{~cm} \times 2 \mathrm{~cm}$ $\times 0.2 \mathrm{~cm}$ each, and the space between electrodes was $1 \mathrm{~cm}$. The effective area of electrode used during a given experiment depends on the studied electrocoagulation parameter. Before each treatment, electrodes were prepared as follows: (1) washed with distilled water, (2) put in alcohol $(90 \%)$ to be sterilized, (3) rinsed with distilled water and dried in the incubator at $110{ }^{\circ} \mathrm{C}$. A magnetic stirrer (Stuart heat-stir SB 162) was employed to homogenize the solution during the experiment. The current was provided by a laboratory DC power supply (ERMES M10SP-303 30 V-3 A). After each treatment, conductivity and $\mathrm{pH}$ were measured by a multi-parameter apparatus (Multi 340i/SET Weight Watchers International $\mathrm{pH}$-meter) and turbidity was measured by a portable turbidimeter (TURBIQUANT 1000 IR).

Treatment procedures and enumeration of E. coli

E. coli (strain ATCC 833), provided by Centre Pasteur of Yaounde-Cameroon, was used as an indicator bacterium in all experiments. The pure strain of E. coli as provided was used to prepare an artificial solution of $E$. coli at concentration $10^{8} \mathrm{UFC} / 100 \mathrm{~mL}$. For each group of experiments, $5 \mathrm{~mL}$ of this solution was diluted into deionized and sterilized water to reach a final concentration of $10^{5} \mathrm{UFC} / 100 \mathrm{~mL}$ after what supporting electrolyte was added to increase the conductivity of the solution. The initial $\mathrm{pH}$ of the solutions was taken equal to 7.1, since the efficiency of the electrocoagulation process reaches its maximum around pH 7 (Chen et al. 2000; Igne 1998). For each treatment, $50 \mathrm{~mL}$ of the above inoculated water was introduced in the technical reactor and the treated water was then collected and filtered using Whatman filter paper no $40(2.5 \mu \mathrm{m})$, before the enumeration.

The concentration of $E$. coli was determined using the membrane filtration method with appropriate culture media 
[lactose TTC (2,3,5-triphenyltetrazolium chloride) agar with tergitol 7 base]. An incubation time of 24-48 h at $44{ }^{\circ} \mathrm{C}$ was allowed to the colonies to develop (Sloat and Ziel 1992). Experiments were replicated three times for statistical reasons. The inactivation efficiency of $E$. coli was determined for each treatment taking into account the number of $E$. coli in the solution and expressed as log units.

\section{Effect of electrocoagulation parameters}

\section{Charge loading}

Charge loading is defined as the quantity of electricity (in Faraday) per unit volume of a treated solution; the quantity of ions produced in solution during the electrocoagulation process depends on this parameter which influences strongly the pollutants elimination rate and the mechanisms of the process (Chen et al. 2000; Kumar et al. 2004). The effect of this key parameter was evaluated by varying the treatment time from 0 to $40 \mathrm{~min}$, while the volume of the solution $(50 \mathrm{~mL})$ as well as the current density was maintained constant.

\section{Charge density}

The current density is the current per unit surface of each immersed electrode (Chen et al. 2000). Some investigators have reported that current density can influence the treatment efficiency (Pouet and Grasmick 1995), but their conclusion was based on experimental conditions where the charge loading also varied. Other investigators have shown that the current density had no effect on the removal efficiency of electrocoagulation (Chen et al. 2000). During our study of the effect of this parameter on the inactivation of E. coli, the charge loading was maintained constant. The current density was varied either by changing the immersed electrode surface while the current itself and the wastewater retention time were maintained constant or by varying both the wastewater retention time and the current (from 0.1 to $0.5 \mathrm{~A}$ ) while the immersed electrode surface was maintained constant.

\section{Electrode material}

Electrocoagulation when used as an electrochemical disinfection technic proceeds through the electrogeneration of oxidants in solution a phenomenon which depends on several key parameters, including the nature of electrode material, the electrolyte composition, the applied current (or voltage), the $\mathrm{pH}$ and the temperature. Among these parameters, the electrode material has been shown to be the most important one as it governs the nature and the yield of the oxidants species generated (Cañizares et al. 2005;
Furuta et al. 2004; Martinez-Huitle et al. 2008). For a better understanding of the effect of the nature of electrode material on $E$. coli inactivation by electrocoagulation, three different electrodes (ordinary steel, aluminum and graphite) were tested with varying charge loading and $\mathrm{NaNO}_{3}$ as supporting electrolyte. As a matter of fact, ordinary steel and aluminum are dissolved during the process (Chen et al. 2000; Yildiz et al. 2008), which is not the case which carbon graphite. Yet some dissolution of the carbon is observed due to $\mathrm{Cl}^{-}$attack when the experiment is conducted in the presence of this electrolyte (Entwisle 1974). However, this does not lead to the formation of metallic species (cations) and flocs like in the case of aluminum or ordinary steel. Moreover, $\mathrm{NaNO}_{3}$ is used as supporting electrolyte because electrocoagulation in the presence of sulfates must be avoided when operating with aluminum electrodes since sulfates anions have a harmful influence on electrical consumption and electrocoagulation efficiency (Trompette and Vergnes 2009).

\section{Supporting electrolyte}

Supporting electrolyte plays an important role during electrocoagulation process as its nature and concentration increase significantly the conductivity of the solution (Gao et al. 2010; Izquierdo et al. 2010; Yildiz et al. 2008). The production of some oxidants in solution also depends on the type of supporting electrolyte used (Cañizares et al. 2005). Strong supporting electrolytes such as sodium chloride $(\mathrm{NaCl}, 99.8 \%$ from Prolabo), sodium sulfate $\left(\mathrm{Na}_{2} \mathrm{SO}_{4}, 99 \%\right.$ from Acros) and sodium nitrate $\left(\mathrm{NaNO}_{3}\right.$, $99 \%$ from Prolabo), each at a concentration of $1 \mathrm{~g} / \mathrm{L}$, were used in order to examine the effect of supporting electrolyte type on the inactivation of $E$. coli by electrocoagulation.

\section{Results and discussion}

\section{Effect of charge loading}

Table 1 illustrates the effect of the charge loading between 0 and $37.5 \mathrm{~F} / \mathrm{m}^{3}$ on the conductivity, turbidity, $\mathrm{pH}$ and energy consumption, while Fig. 1 shows the effect of the charge loading on the inactivation efficiency expressed as unit of colony formed by $100 \mathrm{~mL}$ of treated solution (UFC/ $100 \mathrm{~mL})$.

On examining the data in Table 1, it appears that apart from conductivity which remains constant at $1.5 \mathrm{~ms} / \mathrm{cm}$, turbidity and $\mathrm{pH}$ vary as charge loading is changed. Indeed, a sharp decrease in the turbidity is noted once the charge loading increases, passing from $13 \mathrm{NTU}\left(0 \mathrm{~F} / \mathrm{m}^{3}\right)$ to $7 \mathrm{NTU}\left(1.24 \mathrm{~F} / \mathrm{m}^{3}\right)$; the turbidity then remains constant 
even with higher values of charge loading. It can be seen that a pH increase occurs between 0 and $12.43 \mathrm{~F} / \mathrm{m}^{3}$, a maximum value of $\mathrm{pH}=9.1$ is obtained for $12.43 \mathrm{~F} / \mathrm{m}^{3}$ followed by a $\mathrm{pH}$ drop for higher values of charge loading. These variations in final $\mathrm{pH}$ in function of charge loading are usually observed when electrocoagulation is used for wastewater treatment (Chen et al. 2000).

E. coli concentration is strongly reduced as charge loading increases (Fig. 1), passing from $5.7 \mathrm{log}$ units at $0 \mathrm{~F} / \mathrm{m}^{3}$ to $3.34 \log$ units at $6.21 \mathrm{~F} / \mathrm{m}^{3}$ which correspond to inactivation efficiency of $99.51 \%$. Almost no bacterium remains alive at $37.30 \mathrm{~F} / \mathrm{m}^{3}$, i.e., after a 30 -min retention time. The analysis of the resulting flocs does show that E. coli are effectively killed. Similar results were obtained by Ghernaout et al. (2008) when they applied electrocoagulation in the $E$. coli culture and the two surface waters. In fact, they noted that, some either the initial $\mathrm{pH}$ and with ordinary iron electrodes, a wastewater retention time of at

Table 1 Evolution of some water parameters (before and after treatment) with charge loading: current density $12.5 \mathrm{~mA} / \mathrm{cm}^{2}$; supporting electrolyte $\mathrm{Na}_{2} \mathrm{SO}_{4}$; electrode material: ordinary steel; initial $\mathrm{pH} 7.1$

\begin{tabular}{lllll}
\hline $\begin{array}{l}\text { Charge } \\
\text { loading } \\
\left(\mathrm{F} / \mathrm{m}^{3}\right)\end{array}$ & $\begin{array}{l}\text { Conductivity } \\
(\mathrm{mS} / \mathrm{Cm})\end{array}$ & $\mathrm{pH}$ & $\begin{array}{l}\text { Turbidity } \\
(\mathrm{NTU})\end{array}$ & $\begin{array}{l}\text { Energy } \\
\text { consumption } \\
\left(\mathrm{Kwh} / \mathrm{m}^{3}\right)\end{array}$ \\
\hline 0.00 & 1.548 & 7.1 & 13.0 & 0.000 \\
1.24 & 1.533 & 7.2 & 7.0 & 0.280 \\
3.73 & 1.533 & 7.6 & 7.2 & 0.813 \\
6.21 & 1.575 & 8.2 & 7.1 & 1.310 \\
9.95 & 1.575 & 9.0 & 7.1 & 2.010 \\
12.43 & 1.596 & 9.1 & 7.0 & 2.494 \\
18.65 & 1.473 & 8.8 & 7.0 & 3.676 \\
24.87 & 1.548 & 8.6 & 7.1 & 4.859 \\
37.30 & 1.598 & 8.5 & 7.0 & 7.193 \\
\hline
\end{tabular}

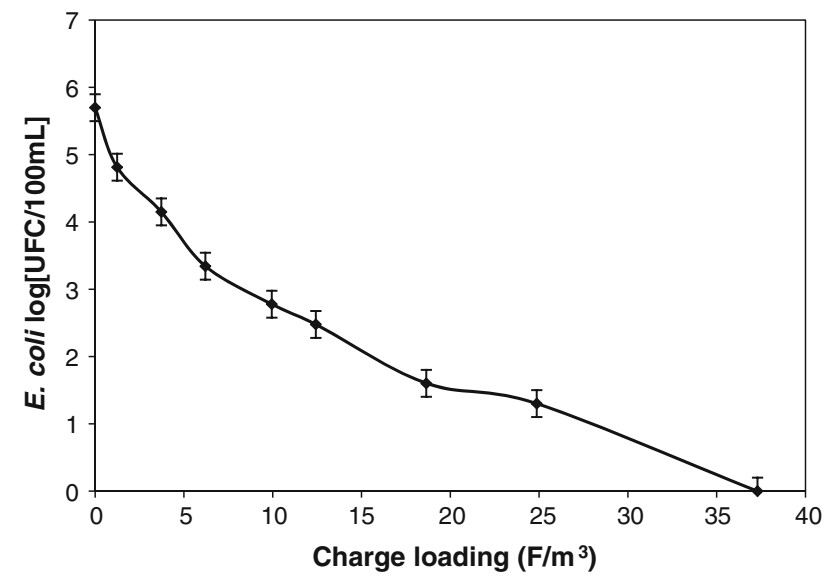

Fig. 1 Effect of charge loading on inactivation of E. coli: current density $12.5 \mathrm{~mA} / \mathrm{cm}^{2}$; initial $\mathrm{pH} 7.1$; electrode material: ordinary steel; supporting electrolyte $\mathrm{Na}_{2} \mathrm{SO}_{4}$ least $30 \mathrm{~min}$ is required to have transparent solution, which corresponds according to the method used to efficiency around $100 \%$.

However, the efficiency of inactivation of $E$. coli may be improved by lowering the charge loading. For this to be achieved, many other parameters including current density, the nature of electrode material and the nature of supporting electrolyte have to be checked and optimized.

\section{Effect of current density}

The effect of current density on inactivation of $E$. coli (with initial concentration $5 \times 10^{5} \mathrm{UFC} / 100 \mathrm{~mL}$ ) was studied with the following experimental conditions: Charge loading was maintained constant at $6.21 \mathrm{~F} / \mathrm{m}^{3}$, while current density was varied between 0 and $50 \mathrm{~mA} / \mathrm{cm}^{2}$. The results are shown in Fig. 2. As seen in Fig. 2, it appears that the concentration of $E$. coli decreases significantly between 0 and $12.5 \mathrm{~mA} / \mathrm{cm}^{2}$, where a $3 \log$ reduction in E. coli is observed. For more than $12.5 \mathrm{~mA} / \mathrm{cm}^{2}$, the concentration of $E$. coli remains almost constant on varying the current density. So, the current density has an effect on the inactivation of $E$. coli. Although the current density and thus the immersed electrode surface really affects the treatment efficiency, the charge loading has the most dramatic effect on the inactivation of E. coli, since it is not possible to obtain a total removal of $E$. coli while varying only current density. Therefore, only variation in charge loading was considered for furthering experiments.

However, this observation does not rule out the advantages of using high current density because, by so doing, small immersed electrode surface or less wastewater retention time is sufficient. Hence, the energy consumption required increases with high current density (Fig. 3). There is therefore an optimum current density which depends on

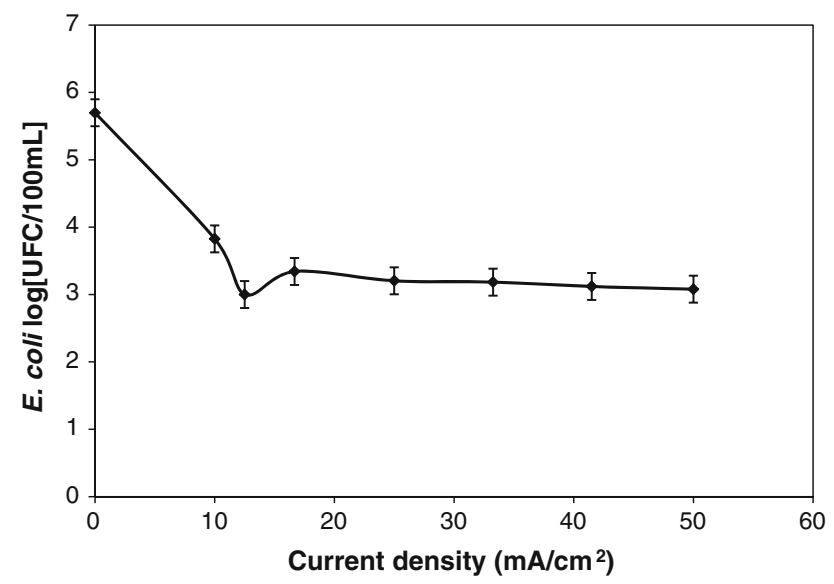

Fig. 2 Effect of current density on inactivation of E. coli: charge loading $6.21 \mathrm{~F} / \mathrm{m}^{3}$; initial $\mathrm{pH} 7.1$; electrode material: ordinary steel; supporting electrolyte $\mathrm{Na}_{2} \mathrm{SO}_{4}$ 


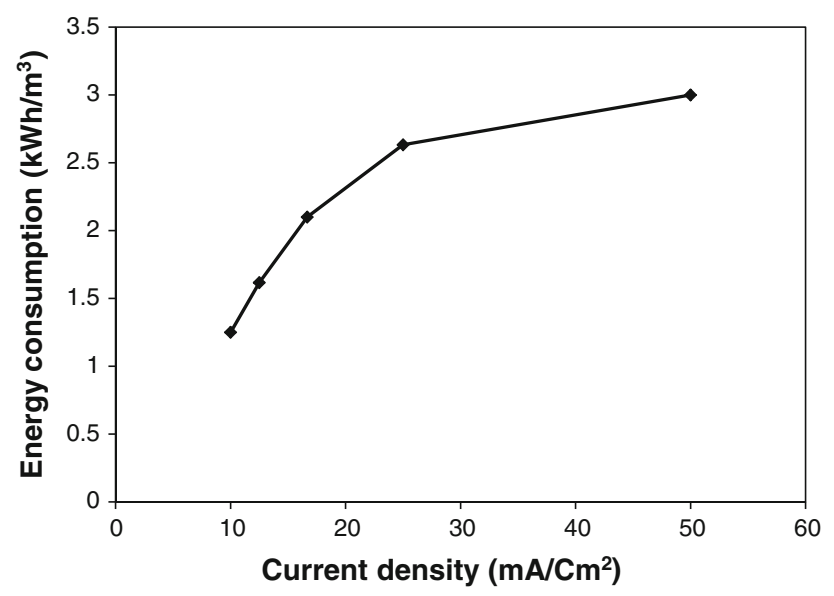

Fig. 3 Effect of current density on energy consumption: charge loading $6.21 \mathrm{~F} / \mathrm{m}^{3}$; initial $\mathrm{pH} 7.1$; electrode material: ordinary steel; supporting electrolyte $\mathrm{Na}_{2} \mathrm{SO}_{4}$

geometrical as well as economical situation where electrocoagulation is applied. In this work, we used optimal current density between 10 and $20 \mathrm{~mA} / \mathrm{cm}^{2}$ under which conditions the energy consumption required is usually lower than $2 \mathrm{kWh} / \mathrm{m}^{3}$ wastewater.

Effect of electrode material on inactivation of $E$. coli

When considering the evolution of the concentration of $E$ coli with respect to electrode material and charge loading, it is noted that the concentration of E. coli is strongly reduced as charge loading increases whatever the type of electrode material (Fig. 4). For a given charge loading, ordinary steel is more efficient than aluminum and carbon graphite. For instance, for a charge loading of $6.21 \mathrm{~F} / \mathrm{m}^{3}$, inactivation efficiencies are 93, 98.8 and $99.95 \%$ for carbon graphite, aluminum and ordinary steel, respectively. In the case of $\log (\mathrm{UFC} / 100 \mathrm{~mL})$, a $1.15,1.92$ and $3.3 \log$ units reduction in E. coli are observed for carbon graphite, aluminum and ordinary steel, respectively. These results do not match those got by Ghernaout et al. in 2008 during the application of electrocoagulation in the $E$. coli culture in two surface waters. In fact, these authors concluded that aluminum is more efficient than ordinary steel. The difference between their result and ours can be explained by the fact that Ghernaout et al. used surface waters, which are known for their hardness $\left(800 \mathrm{mg}\right.$ as $\mathrm{CaCO}_{3} \mathrm{~L}^{-1}$ ), while we used deionized and sterilized water containing sodium sulfate with a concentration of $1 \mathrm{~g} / \mathrm{L}$.

The mechanism that governs the electrochemical disinfection during electrocoagulation derived therefore from three combined effects:

1. A direct effect due to the electric field, which itself is harmful for bacteria cells. It has been shown that this is

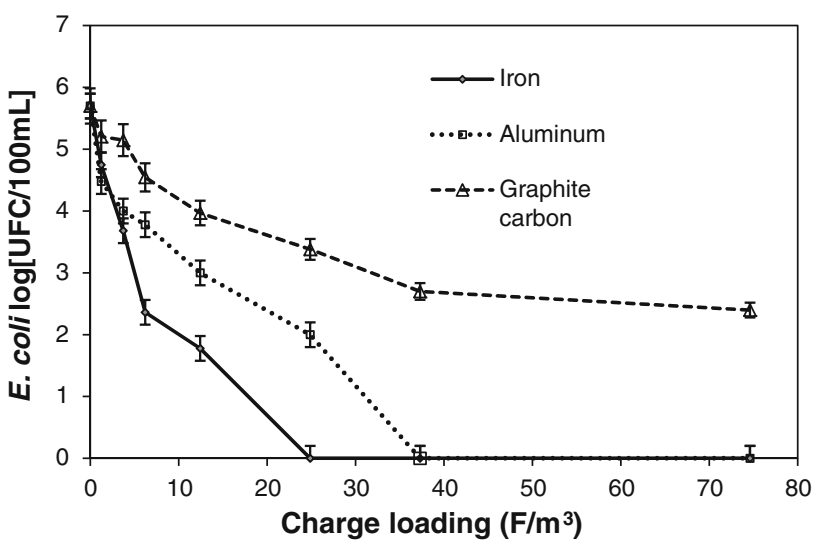

Fig. 4 Effect of charge loading and electrode material on E. coli concentration: current density $12.5 \mathrm{~mA} / \mathrm{cm}^{2}$; initial $\mathrm{pH} 7.1$; supporting electrolyte $\mathrm{NaNO}_{3}$

primarily due to irreversible permeability of the cell membrane when bacteria are exposed to the electric fields (Drees et al. 2003). Electric fields are also capable to destroy cells without damaging their membranes. Vital centers of bacterial cells are protected by a membrane which is constituted essentially by a biomolecular layer of phospholipids with hydrophobic and hydrophilic side. A phospholipids membrane is not easily oxidized, whereas proteins are easily destroyed by direct effect of an electrical field. Cells cannot then exchange more ions but can be, however, reactivated in a favorable medium ( $\mathrm{Li}$ et al. 2004). However, electric field can only reduce the population of bacteria (Drees et al. 2003);

2. The actions of oxidants which are electrogenerated during electrocoagulation such as $\mathrm{ClO}^{-}, \mathrm{ClO}_{2}$, $\mathrm{S}_{2} \mathrm{O}_{8}{ }^{2-}$, etc., depending on the electrolyte used. The total destruction of bacteria requires an oxidant capable of passing through the membrane to reach vital centers ( $\mathrm{Li}$ et al. 2004). According to some investigators, the major mechanism of the inactivation of bacteria in the electrochemical cell is disinfection by electrochemically generated oxidants (Diao et al. 2004; Drees et al. 2003; Jeong et al. 2006);

3. High ionic strength due to metallic species (cations) liberated in solution, which act by charge neutralization on microorganisms (Vega-Mercado et al. 1997), and metallic hydroxides (flocs) formed as a result of coagulation which act by "sweep flocculation or enmeshment" and adsorption (Zhu et al. 2005). In fact, the solid oxides, hydroxides and oxyhydroxides provide active surfaces for the adsorption of the polluting species, and they create a sludge blanket that entraps and bridges colloidal particles in the aqueous medium (Mollah et al. 2004). E. coli removal 
by electrocoagulation was predominantly due to adsorption of the negatively charged $E$. coli onto the positively charged iron and aluminum flocs and the subsequent removal of the flocs by microfiltration. However, E. coli inactivation at high $\mathrm{Fe}(\mathrm{III})$ and Al(III) dosages was attributed to enmeshment prior to removal by microfiltration (Zhu et al. 2005). This effect explains the fact that inactivation efficiency is lowest with carbon graphite, given that no metal cation and no flocs are generated with this electrode. In addition, inactivation efficiency is higher with ordinary steel as electrode material than with aluminum given that iron hydroxides lead to higher enmeshment and adsorption than aluminum hydroxides. For these reasons, ordinary steel electrodes were used in further experiments.

Effect of supporting electrolyte type on E. coli and energy consumption

\section{Effect on E. coli inactivation}

The inactivation of $E$. coli increases significantly with charge loading, whatever the type of supporting electrolyte (Fig. 5). E. col. inactivation was quickly achieved when $\mathrm{NaCl}$ was used followed by $\mathrm{NaNO}_{3}$ and $\mathrm{Na}_{2} \mathrm{SO}_{4}$. A $2.3 \log$, $3.3 \mathrm{log}$ and $3.9 \mathrm{log}$ reductions in $E$. coli were observed for $\mathrm{Na}_{2} \mathrm{SO}_{4}, \mathrm{NaNO}_{3}$ and $\mathrm{NaCl}$, respectively, after $5 \mathrm{~min}$ of treatment which corresponds to a charge loading of $6.21 \mathrm{~F} /$ $\mathrm{m}^{3}$. Total inactivation was achieved at charge loading of 37.3, 24.87 and $12.43 \mathrm{~F} / \mathrm{m}^{3}$ for $\mathrm{Na}_{2} \mathrm{SO}_{4}, \mathrm{NaNO}_{3}$ and $\mathrm{NaCl}$, respectively. These results confirm the importance of electrolyte type on the inactivation of bacteria during electrocoagulation. The inactivation efficiencies are higher for $\mathrm{NaCl}$ than $\mathrm{NaNO}_{3}$ and $\mathrm{Na}_{2} \mathrm{SO}_{4}$. This can be explained

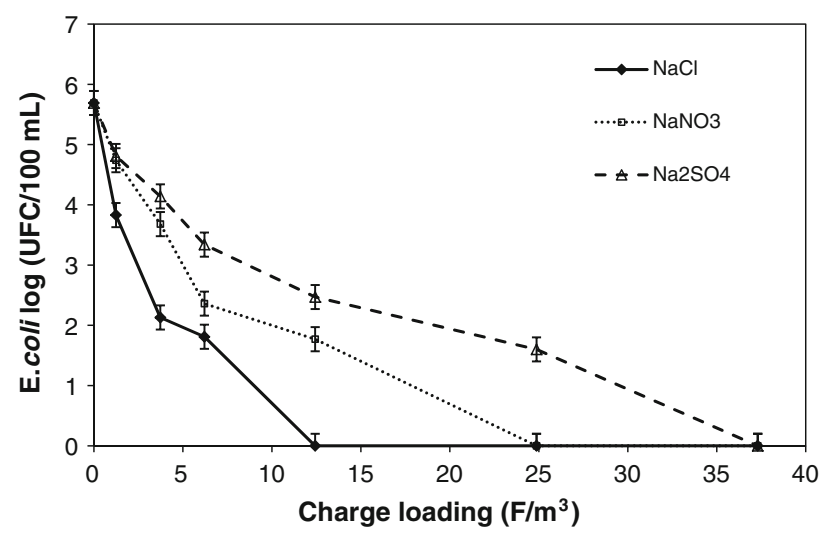

Fig. 5 E. coli inactivation in function of supporting electrolyte: current density $12.5 \mathrm{~mA} / \mathrm{cm}^{2}$; initial $\mathrm{pH} 7.1$; electrode material: ordinary steel by the fact that when ordinary steel is used, the reactions occurring at the surface of the electrodes and in the bulk solution are given by Eqs. (1-7). However, reactions (2), (5) and (6) may take place as secondary reactions, in chloride containing waters (Yildiz et al. 2008).

At anode:

$\mathrm{Fe} \rightarrow \mathrm{Fe}^{2+}+2 \mathrm{e}^{-}$

$2 \mathrm{Cl}^{-} \rightarrow \mathrm{Cl}_{2}+2 \mathrm{e}^{-}$.

At cathode:

$3 \mathrm{H}_{2} \mathrm{O}+3 \mathrm{e}^{-} \rightarrow 3 / 2 \mathrm{H}_{2}(\mathrm{~g})+3 \mathrm{OH}^{-}$.

In the bulk solution:

$\mathrm{Fe}^{2-}+2 \mathrm{OH}^{-} \rightarrow \mathrm{Fe}(\mathrm{OH})_{2}$

$\mathrm{Cl}_{2}+\mathrm{H}_{2} \mathrm{O} \rightarrow \mathrm{HOCl}+\mathrm{H}^{+} \mathrm{Cl}^{-}$

$\mathrm{HOCl} \rightarrow \mathrm{H}^{+}+\mathrm{ClO}^{-}$.

Also under the action of dissolved oxygen, $\mathrm{Fe}^{2+}$ is oxidized to $\mathrm{Fe}^{3+}$ and we can also have the following reaction in bulk solution (Chen et al. 2000):

$4 \mathrm{Fe}^{2+}+10 \mathrm{H}_{2} \mathrm{O}+\mathrm{O}_{2} \rightarrow 4 \mathrm{Fe}(\mathrm{OH})_{3}+8 \mathrm{H}^{+}$.

The above reactions clearly show that electrocoagulation is a process consisting of oxidation, flocculation and flotation. On the one hand, the metallic hydroxides that are formed tend to polymerize because of the interactions between the hydroxyl groups; they then become microflocs, and then big flocs which are responsible for the coagulation and the flocculation (Kumar et al. 2004). On the other hand, different chlorine species formed have been recognized as key oxidants, responsible for the inactivation of microbial cells in electrochemical disinfection (Bergmann and Rollin 2007). It has been demonstrated that chlorine species diffuse through the cell walls, produces a dysfunction in the internal enzyme groups and hence inactivates cells. It also has been reported that chlorine may react with the cell wall materials. For example, chlorine could oxidize the N-terminal amino groups of proteins within the cell wall, which would alter the wall strength and thus kill the cells (Sharma and Venkobachar 1979). All these explain why the inactivation efficiencies are higher for $\mathrm{NaCl}$ than $\mathrm{NaNO}_{3}$ and $\mathrm{Na}_{2} \mathrm{SO}_{4}$.

\section{Effect on energy consumption}

The effect of supporting electrolyte type on energy consumption has been investigated in the same conditions for the inactivation efficiency of $E$. coli. Energy consumption increases with charge loading, whatever the type of the supporting electrolyte (Fig. 6). The highest energy 


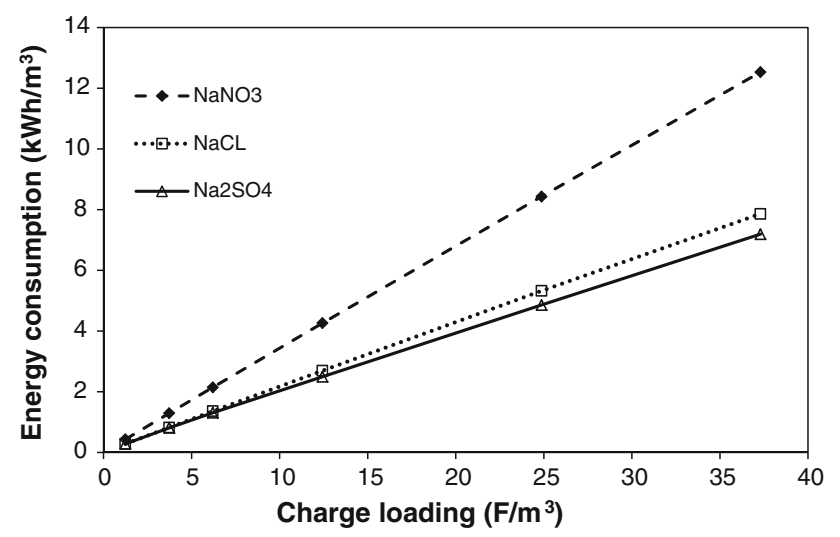

Fig. 6 Energy consumption in function of supporting electrolyte: current density $12.5 \mathrm{~mA} / \mathrm{cm}^{2}$; initial $\mathrm{pH} 7.1$; electrode material: ordinary steel

expenditure is noted for $\mathrm{NaNO}_{3}$ followed by $\mathrm{NaCl}$ and $\mathrm{Na}_{2} \mathrm{SO}_{4}$. This could be bound to the conductivity of the ions present in each electrolyte. Indeed, conductivity of $1.21,1.32$ and $1.57 \mathrm{mS} / \mathrm{cm}$ was noted for $\mathrm{NaNO}_{3}, \mathrm{NaCl}$ and $\mathrm{Na}_{2} \mathrm{SO}_{4}$ solutions, respectively. From Fig. 5, it appears that the inactivation efficiency reaches $100 \%$ when energy consumptions are $8.43,7.19$ and $2.69 \mathrm{kWh} / \mathrm{m}^{3}$ for $\mathrm{NaNO}_{3}$, $\mathrm{Na}_{2} \mathrm{SO}_{4}$ and $\mathrm{NaCl}$, respectively. Thus, $\mathrm{NaCl}$ has the lowest energy consumption to inactivate all the $E$. coli in solution.

Since $\mathrm{NaCl}$ has the highest inactivation efficiency and the lowest energy consumption, it can be said that the most favorable supporting electrolyte for the treatment of wastewater containing $E$. coli by electrocoagulation is $\mathrm{NaCl}$. Similar results were obtained by Kerwick et al. (2005), who found the electrochemical disinfection most effective in water containing chloride in comparison with water containing phosphate and sulfate.

\section{Conclusion}

In the present work, the effect of electrode material and supporting electrolyte on the treatment by electrocoagulation of wastewater containing $E$. coli has been investigated. The obtained results show that charge loading greatly affects the inactivation efficiencies of E. coli; a $5 \mathrm{log}$ reduction in $E$. coli is observed after $30 \mathrm{~min}$ of treatment. A full inactivation of $E$. coli is obtained with charge loading around 37.30 and $24.87 \mathrm{~F} / \mathrm{m}^{3}$ for aluminum and ordinary steel, respectively. Ordinary steel electrode was therefore found to be more efficient than aluminum for E. coli cells destruction. Current density has an effect on the inactivation of $E$. coli by electrocoagulation. Electrochemical disinfection was more effective in water containing chlorine than water containing nitrate and sulfate. For the practical application, the best combination of choices of parameters to inactivate $E$. coli using electrocoagulation is ordinary steel as electrode material and sodium chloride as supporting electrolyte type. The mechanisms of electrochemical disinfection by electrocoagulation can be viewed as the consequence of three combined effects: the electric field, the actions of oxidants which are electrogenerated during the process and the adsorption by the metallic hydroxides formed in solution.

Acknowledgments The authors wish to thank the International Foundation of Science (IFS) and the Organization for Prohibition of Chemical Weapons (OPCW) (Project No. W/4395-1, Dr NanseuNjiki C. P.) for their financial support. They also thank AIRES-Sud, a program from the French Ministry of Foreign and European Affairs implemented by the Institut de Recherche pour le Developpement (IRD-DSF).

\section{References}

Abu-Shkara F, Neeman I, Sheinman R, Armon R (1998) The effect of fatty acid alteration in coliform bacteria on disinfection resistance and/or adaptation. Water Sci Technol 38(12):133-139

Bergmann MEH, Koparal AS (2005) Studies on electrochemical disinfectant production using anodes containing $\mathrm{RuO}_{2}$. J Appl Electrochem 35(12):1321-1329

Bergmann MEH, Rollin J (2007) Product and by-product formation in laboratory studies on disinfection electrolysis of water using boron-doped diamond anodes. Catal Today 124(3-4):198-203

Birbir M, Hacioğlu H, Birbir Y, Altuğ G (2009) Inactivation of Escherichia coli by alternative electric current in rivers discharged into sea. J Electrostat 67(4):640-645

Bull NB, Krasner SW, Daniel P, Bull RD (2001) Health effects and occurrence of disinfection by-products. AWWA Research foundation and American Water Works Association

Cañizares P, Larrondo F, Lobato J, Rodrigo MA, Sáez C (2005) Electrochemical synthesis of peroxodiphosphate using borondoped diamond anodes. J Electrochem Soc 152(11):191-196

Chen X, Chen G, Yue PL (2000) Separation of pollutants from restaurant wastewater by electrocoagulation. Sep Purif Technol 19(1-2):65-76

Diao HF, Li XY, Gu JD, Shi HC, Xie ZM (2004) Electron microscopic investigation of the bactericidal action of electrochemical disinfection in comparison with chlorination, ozonation and Fenton reaction. Process Biochem 39(11):1421-1426

Drees KP, Abbaszadegan M, Maier RM (2003) Comparative electrochemical inactivation of bacteria and bacteriophage. Water Res 37(10):2291-2300

Driedger AM, Rennecker JL, Marinas BJ (2000) Sequential inactivation of Cryptosporidium parvum oocysts with ozone and free chlorine. Water Res 34(14):3479-3493

Entwisle JH (1974) Consumption of graphite anodes in chlorine manufacture by brine electrolysis. J Appl Electrochem 4(4):293-303

Essadki AH, Bennajah M, Gourich B, Vial Ch, Azzi M, Delmas H (2008) Electrocoagulation/electroflotation in an external-loop airlift reactor-application to the decolorization of textile dye wastewater: a case study. Chem Eng Proc Process Intensif 47(8):1211-1223

Furuta T, Tanaka H, Nishiki Y, Pupunat L, Haenni W, Rychen P (2004) Legionella inactivation with diamond electrodes. Diamond Relat Mater 13:2016-2019 
Gao S, Du M, Tian J, Yang J, Yang J, Ma F, Nan J (2010) Effects of chloride ions on electro-coagulation-flotation process with aluminium electrodes for algae removal. J Hazard Mater 182(1-3):827-834

Ghernaout D, Badis A, Kellil A, Ghernaout B (2008) Application of electrocoagulation in Escherichia coli culture and two surface waters. Desalination 219(1-3):118-125

Igne V (1998) 'Traitement des effluents liquides par electrocoagulation-flocculation. Dossier d'actualisation (CFE), centre français d'électricité-pôle technique et veille, Paris, 8-19

Izquierdo CJ, Cañizares P, Rodrigo MA, Leclerc JP, Valentin G, Lapicque F (2010) Effect of the nature of the supporting electrolyte on the treatment of soluble oils by electrocoagulation. Desalination 255(1-3):15-20

Jeong J, Kim JY, Yoon J (2006) The role of reactive oxygen species in the electrochemical inactivation of microorganisms. Environ Sci Technol 40(19):6117-6122

Jeong J, Kim C, Yoon J (2009) The effect of electrode material on generation of oxidants and microbial inactivation in the electrochemical disinfection processes. Water Res 43(4):895-901

Kerwick MI, Reddy SM, Chamberlin AHL, Holt DM (2005) Electrochemical disinfection, an environmentally acceptable method of drinking water disinfection? Electrochim Acta 50(25-26):5270-5277

Kumar PR, Chaudhari S, Khilar KC, Mahajan SP (2004) Removal of arsenic from water by electrocoagulation. Chemosphere 55(9):1245-1252

Li M, Qu JH, Peng YZ (2004) Sterilization of E. coli cells by the application of pulsed magnetic field. J Environ Sci 16(2): 348-352

Longley KE (1986) Wastewater disinfection, manuals of practice for water pollution control. Water pollution control federation, Alexandria

Martinez-Huitle CA, Brillas E (2008) Electrochemical alternatives for drinking water disinfection. Angwante Chemie 47(11):19982005
Mollah MYA, Morkovskyb P, Gomes JAG, Kesmez M, Pargad J, Cocke DL (2004) Fundamentals, present and future perspectives of electrocoagulation. J Hazard Mater 114(1-3):199-210

Nanseu-Njiki CP, Tchamango SR, Ngom PC, Darchen A, Ngameni E (2009) Mercury(II) removal from water by electrocoagulation using aluminium and iron electrodes. J Hazard Mater 168(2-3): $1430-1436$

Panizza M (2010) Importance of electrode material in the electrochemical treatment of wastewater containing organic pollutants (ch. 2). In: Comninellis C, Chen G (eds) Electrochemistry for the environment. Springer Science + Business Media, LLC, New York, pp 25-54

Pouet MF, Grasmick A (1995) Urban wastewater treatment by electrocoagulation and flotation. Water Sci Technol 31(3-4): 275-287

Sharma AK, Venkobachar C (1979) Effect of prechlorination on coagulation of algae. India J Environ Health 21(1):16-22

Sloat S, Ziel C (1992) The use of indicator organisms to assess public water safety. Technical Information series-Booklet No.13. $\mathrm{HACH}$ technical centre for applied analytical chemistry, $\mathrm{HACH}$ Compagny, Loveland, Colorado USA, 1-15

Trompette JL, Vergnes H (2009) On the crucial influence of some supporting electrolytes during electrocoagulation in the presence of aluminum electrodes. J Hazard Mater 163(1-2):1282-1288

Vega-Mercado H, Pothakamury UR, Chang FJ, Barbosa-Cánovas GV, Swanson BG (1997) Inactivation of E. coli by combining $\mathrm{pH}$, ionic strength and pulsed electric fields hurdles. Food Res Int 29(2):117-121

Yildiz YS, Koparal AS, Keskinler B (2008) Effect of initial pH and supporting electrolyte on the treatment of water containing high concentration of humic substances by electrocoagulation. Chem Eng J 138(1-3):63-72

Zhu B, Clifford DA, Chellam S (2005) Comparison of electrocoagulation and chemical coagulation pretreatment for enhanced virus removal using microfiltration membranes. Water Res 39(13):3098-3108 